Page 1 of 2 Proj.

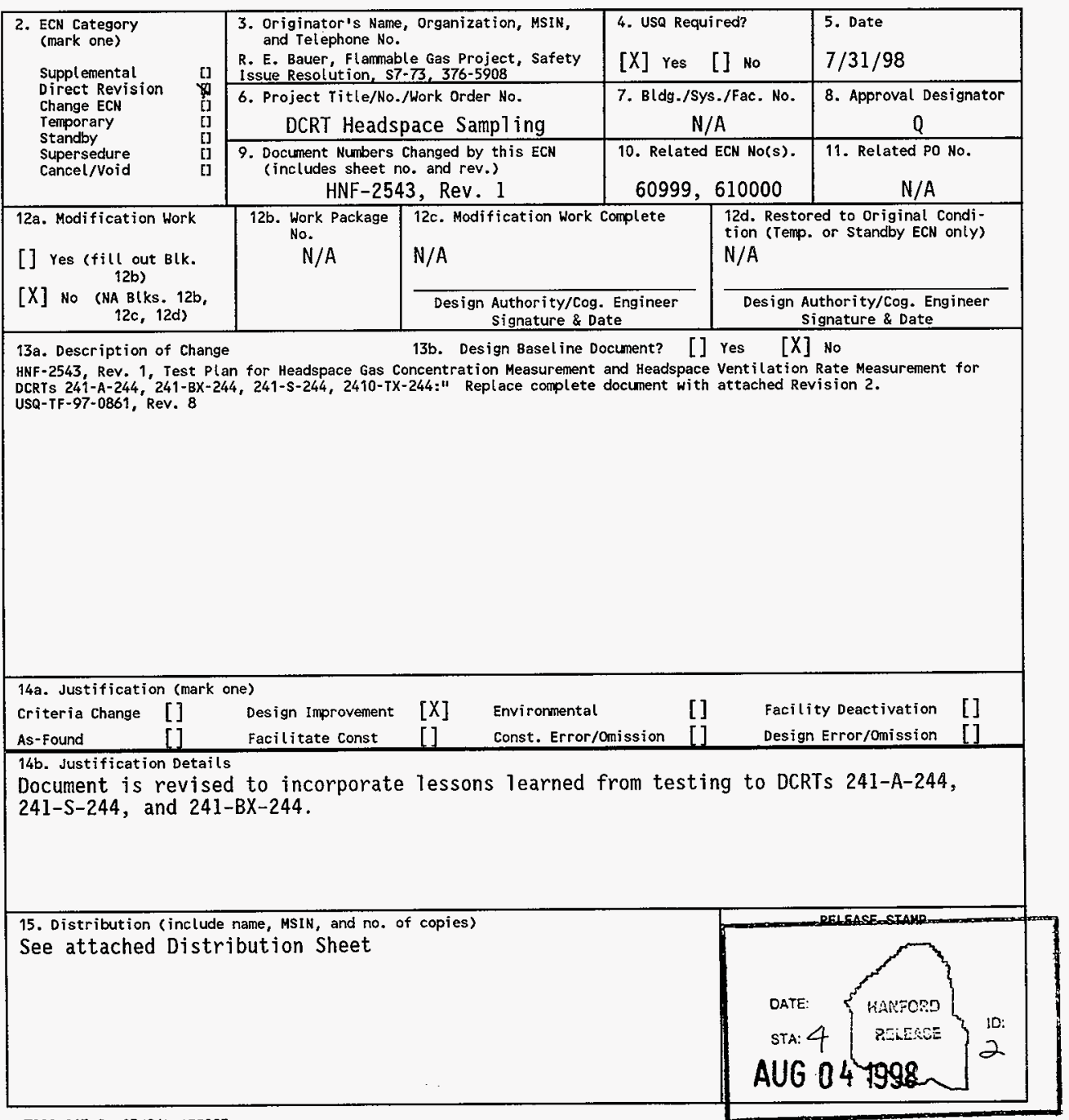




\section{Test Plan for Headspace Gas Concentration Measurement and Headspace Ventilation Rate Measurement for DCRTs 241-A-244, 241-BX-244, 241-S-244, 241-TX-244}

\section{R. E. Bauer}

DESH, Richland, WA 99352

U.S. Department of Energy Contract DE-AC06-96RL13200

$$
\cos 35 \mathrm{~s}>
$$

$\mathrm{EDT} / \mathrm{ECN}:-613764-2 / 4 \mathrm{~s}$

Org Code: N2160

UC: 2030

Charge Code: N23EA

B\&R Code:

Total Pages: 19

Key Words: OCRT, FLAMMABLE GAS, VENTILATION RATE

Abstract: This test plan provides the directions to characterize the headspace gas concentrations and the headspace ventilation rate for double contained receiver tanks 241-A-244, 241-BX-244, 241-S-244, and 241-TX-244.

SUMMA is a trademark of Molectrics, Inc.

TRADEMARK DISCLAIMER. Reference herein to any specific commercial product, process, or service by trade name, trademark, manufacturer, or otherwise, does not necessarily consticute or imply its endorsenent, recommendation, or favoring by the United States Government or any agency thereof or its contractors or subcontractors.

Printed in the United States of America. To obtain copies of this document, contact: Document Control Services, P.0. Box 950, Mailstop H6-08, Richland WA 99352, Phone (509) 372-2420; Fax (509) 376-4989.
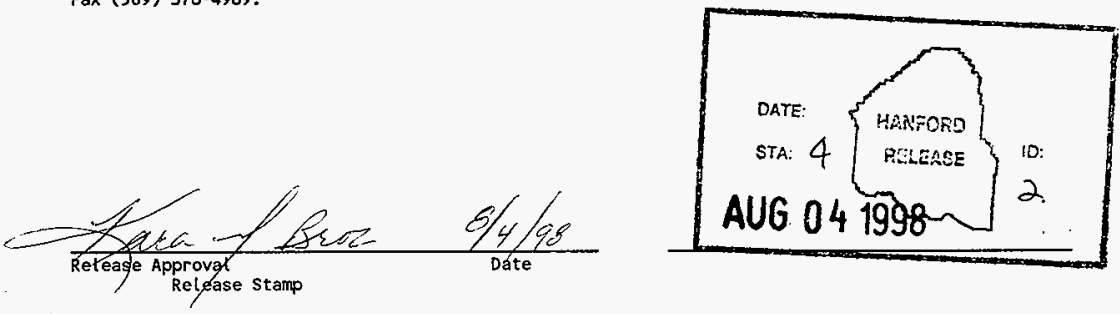
(2) Title

Test Plan for Headspace Gas Concentration Measurement and Headspace Ventilation rate Measurement for DCRTs 241-A-244, 241-BX-244, 241-S-244, 241-TX-244

CHANGE CONTROL RECORD

\begin{tabular}{|c|c|c|c|}
\hline \multirow{2}{*}{ Revision } & \multirow{2}{*}{ (4) Description of Change - Replace, Add, and Delete Pages } & \multicolumn{2}{|c|}{ Auchorized for Retease } \\
\hline & & (5) Cog. Engr. & (6) Cog. Mgr. \\
\hline & (7) Replace pages $10,12,13,14$, and 21 & R. E. Bauer & R. J. Cash \\
\hline 1 & Complete Revision ECN-61000 & R. E. Bauer & R. J- \&ash \\
\hline $2 R S$ & Complete Revision ECN-623527 & R.FEY Bauer & R. T. $\operatorname{Tash}^{3} 7 / 519$ \\
\hline & & & \\
\hline & & & \\
\hline & & & \\
\hline & & & \\
\hline & & & \\
\hline & & & \\
\hline & & & \\
\hline & & & \\
\hline & & & \\
\hline & & & \\
\hline & & & \\
\hline & & & \\
\hline & & & \\
\hline & & & \\
\hline & & & \\
\hline & & & \\
\hline & & & \\
\hline & & & \\
\hline & & & \\
\hline & & & \\
\hline & & & \\
\hline & & & \\
\hline & & & \\
\hline & & & \\
\hline & & & \\
\hline & & & \\
\hline & & & \\
\hline & & & \\
\hline & & & \\
\hline & & & \\
\hline & & & \\
\hline
\end{tabular}




\subsection{PURPOSE OF TEST}

The purpose of this test is to characterize Double Contained Receiver Tanks (DCRTs) 241-A244, 241-BX-244, 241-S-244, and 241-TX-244 headspace gas composition and headspace ventilation rate. This information will be used to support the safety analysis and closure of the Flammable Gas Unreviewed Safety Question for these facilities. This task is performed in support of Tank Safety Issue Resolution activity FGW8020.

\subsection{DESCRIPTION OF TEST}

The Objective of this test is to measure the baseline gas composition and ventilation rate of the tank headspace. This is accomplished using sampling and tracer gas injection methods that have been successfully applied to single-shell tanks (SSTs) (Huckaby 1997). Revision 1 of this document incorporates lessons learned in the initial testing of DCRT 241-TX-244. Initial testing of DCRT 241-TX-244 was accomplished using Revision OA of this document. Revision 2 of this document incorporates lessons learned in subsequent testing. Testing of DCRTs 241-A-244, 241-S-244, and 241-BX-244 were accomplished using Revision 1.

Prior to the tracer gas injection, a set of three baseline SUMMA ${ }^{T M}$ canister samples will be collected from the headspace through the sample point. These samples will become the baseline samples for the tank to establish the gas concentrations. Prior to the baseline samples being taken the sampling system shall be purged using a Combustible Gas Meter (CGM) or Organic Vapor Monitor (OVM) to fill the sample system fubing with headspace gas. The requirements for analysis of these samples are given in section 4.0.

Helium will be injected into the headspace of the designated tank through the assigned injection point as specified by the vapor cognizant engineer. The volume of helium injected will be specified by the vapor cognizant engineer and will be determined from the measured pressure decrease of the helium supply. The flow rate of the tracer gas being injected into the tank will be controlled to less than $227 \mathrm{~L} / \mathrm{min}(8 \mathrm{CFM})$ by the use of an orifice. Within one to four hours following completion of the helium injection, the second set of SUMMA'M canister samples will be collected. These samples will establish the starting helium concentration for the tracer gas measurement. After approximately one day following completion of the tracer gas injection, one more set of three SUMMATM canister samples will be taken. Additional sets of three SUMMA ${ }^{\text {TM }}$ canister samples will be taken if needed at hold times specified by the vapor cognizant engineer. The results from these samples will be utilized to calculate the tank ventilation rate.

\section{$2.1 \quad$ Test Items}

\subsubsection{Equipment and Facilities}

The equipment needed for testing each tank is:

- Tracer gas injection system (Figure 1 and 2). This is the existing equipment used in the gas injection/sampling of SSTs,

- SUMMA ${ }^{\mathrm{TM}}$ canisters (supplied by Pacific Northwest National Laboratory),

- Particulate air filters for SUMMA ${ }^{T M}$ canisters (supplied by Characterization Project Operations [CPO]), and

- Bottled Helium supply (supplied by CPO). 


\subsubsection{Tracer Gas}

Helium is inert (even in the radiation field of the headspace) and essentially insoluble in the waste. Helium is expected to mix within the headspace in a manner similar to hydrogen. Because it is present in ambient air at about $4 \mathrm{ppmv}$, injection of enough gas to raise the initial concentration to between 4,500 and 10,000 ppmv will result in a measurable range spanning three orders of magnitude. This is adequate for the anticipated range of ventilation rates. It is anticipated that a maximum of thity standard cubic feet of helium will be required to reach the helium concentration levels required by these tests.

\subsection{Data}

The test data that will be required from field operations is identified in the data sheet in Appendix A. Data required from laboratory analysis of the samples is identified in section 4.0.

\subsection{Data Evaluation}

The evaluation and reporting of the data from the SUMMA ${ }^{\text {TM }}$ canisters shall be performed by the Safety Issue Resolution Organization.

\section{$2.4 \quad$ Expected Results}

\subsubsection{Gas species and Concentrations}

The gas species to be measured are those listed in section 4.2. This list is based on results from many vapor samples from the headspaces of single-shell and double shell tanks (DSTs). Since the waste that may be in the DCRTs being tested originated from the SSTs and will eventually be transferred to DSTs, it is expected that the same gas species will be encountered. The concentrations of these gas species are not known and to measure the concentrations is one of the test objectives.

The gases with estimated quantitation limits specified in Table 2 shall be measured by Pacific Northwest from the SUMMA ${ }^{\mathrm{TM}}$ canister samples. Ammonia concentration shall be measured by Industrial Hygiene at the time of the baseline sample collection as discussed in section 4.7.

\subsubsection{Headspace Ventilation Rate}

The headspace of the DCRT system receiver tank is actively ventilated, however a dedicated air inlet is not provided for the tank. Therefore, purge air is supplied to the tank headspace by in leakage through tank penetrations or from the process instruments. Ventilation through the headspace is expected to be bounded on the low end by the purge flow through the instrument tubes of approximately $4 \mathrm{cfh}$ (cubic feet per hour) and on the high end by the exhaust rate of the DCRT system exhauster of approximately 100-125 cfm (cubic feet per minute). The actual ventilation rate is expected to be in the range of $1-10 \mathrm{cfm}$ (Peurrung 1998).

The ventilation rate in the receiver tank will be calculated from the measured decay in concentration of an injected tracer gas (helium) between two or more points in time. The initial concentration of the tracer gas will be measured after injection of the helium. Previous testing in waste tank 241-S-102 has demonstrated that tracer mixing in the headspace is essentially complete after one hour (Huckaby 1997). The starting concentration will also be estimated using the estimated volume of the tank headspace and the measured volume of injected helium. The final concentration(s) will be measured from vapor sample(s) obtained after the specified holding time(s). 


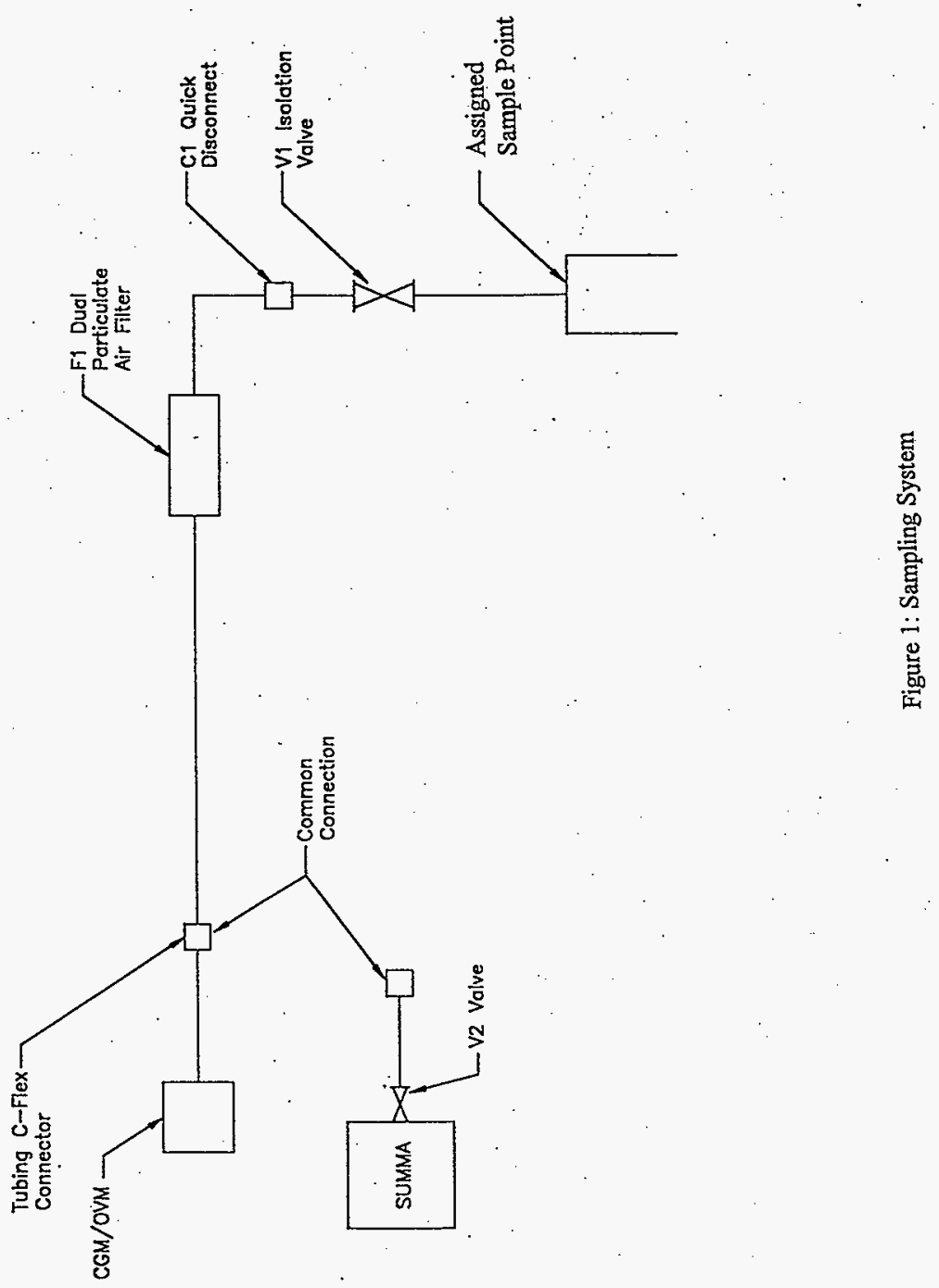




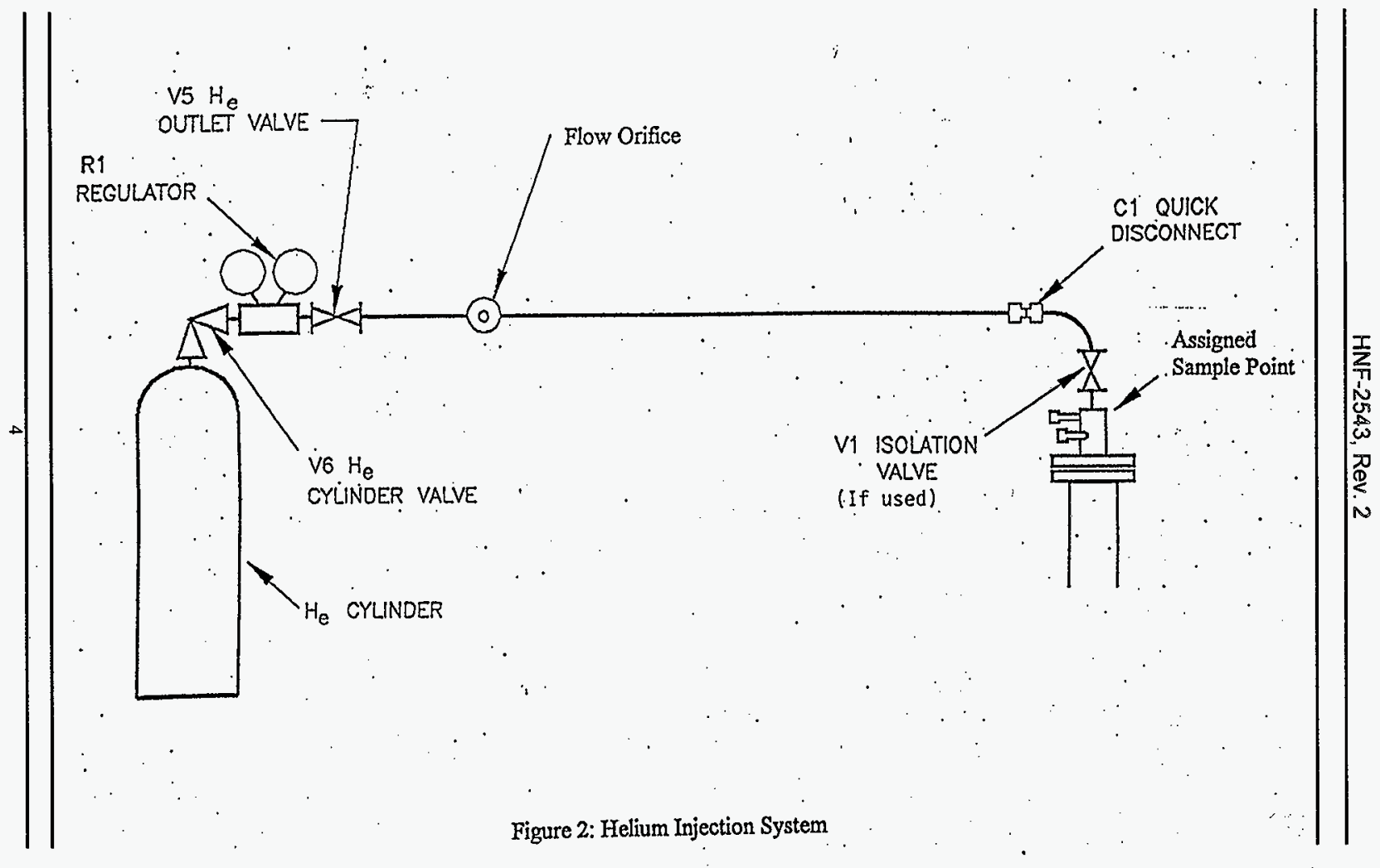


The hold time between injection of the tracer and collection of the final sample will depend on the tank headspace volume, initial concentration, and the desired resolution of the breathing rate. If the helium concentration decays to below $10 \mathrm{ppmv}$ (detection limit), then the only conclusion that can be drawn is that the breathing rate must be equal to or greater than the breathing rate calculated using this time lapse. Therefore, the resolution of the ventilation rate desired (i.e. is it desired to know if it is greater than 1,5 , or $10 \mathrm{cfm}$ ) will set the hold time prior to obtaining the final sample.

\subsection{ROLES AND RESPONSIBILITIES}

\subsection{Safety Issue Resolution}

The Safety Issue Resolution (SIR) Organization is responsible for the test engineer functions including test specification, test results interpretation and reporting, assignment of task responsibilities, and funding of test tasks.

\subsection{Characterization Project Operations}

The Characterization Project Operations (CPO) organization is responsible for test planning by generation of the work packages and engineering documents required to perform the field sampling activities and performance of the activities specified in the field work packages (preparations for sampling, sample collection, sample shipment, etc.). CPO is responsible for supplying the materials and equipment as specified in section 2.1.1. The vapor cognizant engineer is a member of the CPO organization.

\subsection{Pacific Northwest National Laboratory (Pacific Northwest)}

Pacific Northwest is responsible for analysis of the vapor samples per section 4.0 and reporting of the results to SIR. . Pacific Northwest is also responsible for supplying the SUMMA ${ }^{\text {TM }}$ canisters specified in section 2.1.1.

\subsection{Sample Analysis}

Sample analyses performed for the Flammable Gas Project for this set of tests shall be conducted in a manner that conforms to the following requirements. The analytical method to be used is Quantitative Gas Mass Spectrometry per procedure PNL-ALO-284.

\subsection{Compliance with Hanford Analytical Services Quality Assurance Requirements Document (HASQARD)}

Measurement systems used and chemical analysis conducted in support of this test shall conform with the requirements specified in DOE/RL-96-68, Hanford Analytical Services Quality Assurance Requirements Document (HASQARD) (DOE-RL 1996) and any subsequent revisions. Representatives of Lockheed Martin Hanford Corporation may evaluate laboratories providing these measurement services to determine conformance with HASQARD requirements. The Pacific Northwest laboratory implements the HASQARD requirements through MCS-027A, Rev. 4. This QA Plan was evaluated against HASQARD in fiscal year (FY) 1998. 


\subsection{Target Analytes}

The analytes quantified and reported by the performing laboratory shall consist of the following analytes, associated estimated quantitation limits (EQL), precision, and accuracy:

Table 2. Target Gas Analytes

\begin{tabular}{|l|c|c|c|}
\hline \multicolumn{1}{|c|}{ Anaiyte } & EQL (Mole Percent) & $\begin{array}{c}\text { Precision } \\
\text { (\% RDS or \%RPD) }\end{array}$ & $\begin{array}{c}\text { Accuracy (\% } \\
\text { Recovery) }\end{array}$ \\
\hline Argon & 0.1 & 20 & 80 to 120 \\
\hline Carbon monoxide & 0.1 & 20 & 80 to 120 \\
\hline Carbon dioxide & 0.1 & 20 & 80 to 120 \\
\hline Helium & 0.1 & 20 & 80 to 120 \\
\hline Hydrogen & 0.1 & 20 & 80 to 120 \\
\hline Methane & 0.1 & 20 & 80 to 120 \\
\hline Nitrogen & 0.1 & 20 & 80 to 120 \\
\hline Oxygen & 0.1 & 20 & 80 to 120 \\
\hline Nitrous oxide & 0.1 & 20 & 80 to 120 \\
\hline Ammonia $\left(\mathrm{NH}_{3}\right.$ ) & -- & -- & - \\
\hline Other gases & 0.1 & 20 & 80 to 120 \\
\hline
\end{tabular}

Analytes of interest are reported in mole percent. Absolute concentrations are not reported. The Laboratory Control Standard (LCS) results will be reported with the sample results.

\subsection{Quality Control Requirements}

Performing laboratories shall implement a documented system of quality control (QC) to ensure that data generated for this project will be of known and documented quality. Laboratory standard operating procedures shall specify qualitative and quantitative acceptance criteria for quality control activities and corrective action measures to be taken when QC criteria are not satisfied.

The formalized quality control system shall include initial equipment calibration; periodic calibration verification; and analysis of laboratory duplicates, blanks, and control samples. This QC system will document that the analytical process is in a state of control while actual samples are being analyzed, that precision and accuracy requirements have been met, and that the measurement system is free of contamination.

The LCS for the gas mass spectrometry analytical technique will be ambient air. The LCS will be analyzed in duplicate, weekly.

For the gas mass spectrometry analytical technique, precision is measured daily by analyzing "pure" nitrogen in triplicate. The accuracy of analysis is determined by summing the partial pressures of the gases and comparing the result to the total pressure. The determination that corrective action is necessary is based upon the comparison of partial pressure to total pressure. If the pressures are not comparable, then corrective action is taken. Analyte identification is based upon spectral fingerprints. Any analyte of interest exhibiting reliable spectra is reported. 


\section{$4.4 \quad$ Laboratory Records}

Records kept by the performing laboratories shall document the calibration and maintenance of instrumentation and the use of standards to verify instrument accuracy in this activity. Personnel performing the analyfical work will have records showing their training and performance is appropriate to the work being done. Analytical procedures will include the analytical process and the quality controis checks and criteria in place and met at the time of actual sample analysis.

These records shall be kept, organized, protected, and maintained in a manner that ensures their retrieval and review. Records kept in conjunction with the analysis of actual project samples shall be available for review by the customer.

Sufficient records shall be kept or archived by the performing laboratories to enable the customer or the customer's representatives to verify the report data and its quality and to determine who performed the analysis on what equipment on what date and time.

\subsection{Data Review, Validation, and Reporting}

Analysis data must be reviewed and approved prior to release to the customer. One hundred percent of the data must receive an independent technical review by a qualified individual other than the data generator. This review process must be documented and conducted according to standard procedures. The reviewers must release the data, as evidenced by signature, and, as a consequence, ensure the following:

- Data generation and reduction were conducted in a technically correct manner in accordance with the methods used. Data were reported in the proper units and to the correct number of significant figures.

- Calculations have been verified by a valid calculation program, a spot check of verified calculation programs, and/or 100-percent check of all calculations.

- All variances from the accepted method and the rationale for the variations have been documented and approved.

- The data have been reviewed for transcription errors.

- The analytical QC data documentation is complete and includes raw data, calculation records, Chain of Custody forms, callbration records, and QC sample analysis results.

- QC sample analysis results are within established control limits, and if not, the data have been qualified and are supported by adequate explanation.

- Sample holding time requirements, if any, and data reporting requirements, if any, were met or exceptions documented.

Reports of Analysis (ROA) shall be issued by the performing laboratory only to designated Flammable Gas Project personnel. The report shall be shall be signed by the laboratory director, manager, or other person responsible for the quality of the reported data.

ROA shall include each specified target analyte and its sample concentration, the EQL of each target analyte not detected in the sample, and reports of quality control data to document achieved precision, accuracy, and freedom from contamination.

Any difficulties, quality control problems, reanalysis or other pertinent information regarding the analysis procedure shall be included in a narrative describing these events.

\subsection{Helium Tracer Injection Controls}

The helium to be used for the tracer gas is to be $99 \%$ minimum purity. The "prepurified" grade helium available from Hanford Stores is adequate for this application. Since the starting concentration of helium in the tracer test will be established from analysis of the second set of 
samples, certification of the helium purity is not required. The bottle pressure drop required will be specified by the vapor cognizant engineer.

The helium injection is expected to take less than one hour to complete. This time period is expected to be insignificant compared to the time for ventilation exchange of the headspace atmosphere so the injection will be treated in the analysis as occurring as an instantaneous event. The helium is to be injected using one of the tank instrumentation system "dip tubes" that penetrates below the waste surface (if the tank has sufficient contents). This injection meihod is intended to simulate a gas release from the waste.

The start and stop bottle pressure, helium bottle temperature, and tank waste temperature shall be recorded on the data sheet for the helium injection operation. In addition the vendor information for the instruments used for the bottle pressure and temperature measurement shall be included as an attachment to the data sheet.

\subsection{Ammonia and Lower Flammability Limit (LFL) Percent Measurements}

The ammonia concentration and percent LFL in the headspace shall be measured following purging of the sample line with headspace gas and prior to collection of the baseline and third sample. Ammonia shall be measured using colorimetric tubes per Industrial Hygiene Standard Operating Procedure IH-2.3, "Colorimetric Tube Pumps Draeger Gas Detector Pump Models 31 and Accuro," WHC-IP-0030. The percent LFL shall be measured per Industrial Hygiene Standard Operating Procedure $\mathrm{H}-1.4$. "Industrial Hygiene Direct Reading Insirument Survey," WHC-IP-0030. Reporting of the data shall be per Industrial Hygiene Standard Operating Procedure IH-1.5, "Using Industrial Hygiene Monitoring/Sampling Survey Forms," WHC-IP-0030. The measured ammonia concentration and percent LFL shall be recorded on the data sheet along with the Industrial Hygiene report number. A copy of the completed Industrial Hygiene report shall be included as an attachment to the data sheet.

\subsection{SAFETY}

There is no anticipated safety impacts with this testing. The tracer gas injection system has been setup so that it is not possible to over pressurize the tank and all samples will be protected from contamination by double particulate air filters. The equipment being used for the testing is classified as "General Service" per HNF-PRO-704, Table 5. Unreviewed Safety Question screening USQ-TF-97-0861, Revision 5 has been completed for this testing and will be included in the Job Control System work package.

\subsection{TEST PROCEDURE}

Collect the baseline samples, inject the helium tracer gas, and collect the second, third, and any subsequent sample sets per the field work package and the steps listed here. Record the requested information in the data sheet described in Appendix $A$.

\section{Baseline Sample Procedure (Refer to Figure 1)}

6.A1 Connect a single ended, shut-off, quick disconnect body (Swagelok part \#QC4) to the assigned attachment point for the sample.

6.A2 Connect (in series) two particulate air filters to the quick-disconnect installed on the sample line. The particulate air filters (FI) shall be closest to the sample point. 
6.A3 A short piece of c-flex should be placed on the downstream side of the dual particulate air filter (F1). This will allow for the quick connection between the CGM/OVM and SUMMA ${ }^{\mathrm{TM}}$ canisters.

6.A4 Connect the CGM/OVM to the c-flex.

6.A5 Open the sample line isolation valve, $\mathrm{V} 1^{*}$.

6.A6 Purge the sample line using the CGM/OVM for the time specified in the field work package.

6.A7 Measure and record on the data sheet the ammonia concentration and the LFL reading and the time and date of these readings.

6.A8 Close the isolation valve, $\mathrm{V} 1^{*}$.

6.A9 Disconnect the CGM/OVM from the c-flex and connect the SUMMA ${ }^{\text {rM }}$ canister.

6.A10 Open isolation valve, $\mathrm{V} 1^{*}$.

6.A11 Collect the SUMMA ${ }^{T M}$ sample per the field work package and record the data required on the data sheet.

6.A12 Close isolation valve, $\mathrm{V} 1^{*}$.

6.A13 Disconnect the canister from the c-flex and then connect the second canister.

6.A14 Open isolation valve, $\mathrm{V} 1^{*}$.

6.A15 Collect the second SUMMA ${ }^{\text {TM }}$ sample per the field work package and record the data required on the data sheet.

6.A16 Close isolation valve, $\mathrm{V} 1^{*}$.

6.A17 Disconnect the canister from the $\mathrm{c}$-flex and then connect the third canister.

6.A18 Open isolation valve, $\mathrm{V} 1^{*}$.

6.A19 Collect the third SUMMA ${ }^{\mathrm{TM}}$ sample per the field work package and record the data required on the data sheet.

6.A20 Close isolation valve, $\mathrm{V} 1^{*}$.

6.A21 Disconnect the canister from the c-flex.

6.A22 Label and control the three SUMMA ${ }^{\text {TM }}$ canister samples per Appendix A.

6.A23 Configure the Assigned Sample Point to the condition specified in the field work package.

6.A24 Record the DRI number on the data sheet.

"If valve is required, this valve may not be needed for 241-A-244 and 241-S-244 


\section{Helium Tracer Gas Injection Procedure (Refer to Figure 2)}

6.B1 Verify the helium supply is the cylinder prepared (pressure $<900$ psig).

6.B2 Connect the Helium Injection System to the Assigned Sample Point at connection C1 as directed by the field work package.

6.B3 Verify that the helium outlet valve (V5) is closed.

6.B4 Measure the helium cylinder starting pressure by opening the helium cylinder valve (V6), and adjust the pressure regulator as specified in the work package.

6.B5 Record the starting helium cylinder pressure as indicated by the pressure regulator digital high-pressure stage gauge.

6.B6 Measure and record the helium cylinder temperature.

6.B7 Open the assigned sample point isolation valve $(\mathrm{V} 1)^{*}$

6.B8 Begin tracer gas injection by opening the helium outlet valve (V5).

6.B9 Observe the bottle pressure as indicated by the pressure regulator digital high-pressure stage gauge. When the pressure reaches the stopping pressure as specified in the work package, stop helium flow by closing the helium outlet valve (V5).

6.B10 Close the assigned sample point isolation valve (V1)*

6.B11 Verify that the helium outlet valve (V5) is closed.

6.B12 Measure the helium cylinder final pressure using the digital high-pressure stage gauge; record the helium cylinder final (stop) pressure.

6.B13 Close the helium cylinder valve (V6).

6.B14 Disconnect the helium injection system as directed by the field work package.

Second Sample Set Procedure (Refer to Figure 1)

6.C1 Verify that the specified hold time has elapsed since completion of injection of the helium tracer gas.

6.C2 Connect (in series) two particulate air filters to the quick-disconnect installed on the sample line. The particulate air filters (F1) shall be closest to the sample point.

6.C3 A short piece of $\mathrm{c}$-flex should be placed on the down stream side of the dual particulate air filter (F1). This will allow the quick connection between the CGM/OVM and SUMMA ${ }^{\text {TM }}$ canisters.

6.C4 Connect the CGM/OVM to the c-flex.

6.C5 Open the sample line isolation valve, $V 1^{*}$.

6.C7 Close the isolation valve, $\mathrm{V}^{*}$ * 
6.C8 Disconnect the CGM/OVM from the c-flex and connect the SUMMA'M canister.

6.C9 Open isolation valve, $\mathrm{V} 1^{*}$.

6.C10 Collect the SUMMA ${ }^{T M}$ sample per the field work package and record the data required on the data sheet.

6.C11 Close isolation valve, $\mathrm{V} 1^{*}$.

6.C12 Disconnect the canister from the c-flex and then connect the second canister.

6.C13 Open Isolation valve, $\mathrm{V} 1^{*}$.

6.C14 Collect the second SUMMA'M sample per the field work package and record the data required on the data sheet.

6.C15 Close isolation valve, $\mathrm{V} 1^{*}$.

6.C16 Disconnect the canister from the $\mathrm{c}-$ flex and then connect the third canister.

6.C17 Open isolation valve, $\mathrm{V} 1^{*}$.

6.C18 Collect the third SUMMA ${ }^{\mathrm{TM}}$ sample per the field work package and record the data required on the data sheet.

6.C19 Close isolation valve, $\mathrm{V}^{*}$.

6.C20 Disconnect the canister from the c-flex.

6.C21 Label and control the three SUMMATM canister samples per Appendix A.

6.C22 Configure the assigned sample point to the condition specified in the field work package.

Third Sample Set (and any subsequent sample sets) Procedure Refer to Figure 1

6.D1 Connect a single ended, shut-off, quick disconnect body (Swagelok part \#QC4) to the assigned attachment point for the sample.

6.D2 Connect (in series) two particulate air filters to the quick-disconnect installed on the sample line. The particulate air fiters $(F I)$ shall be closest to the sample point.

6.D3 A short piece of $c$-flex should be placed on the down stream side of the dual particulate air filter (F1). This will allow for quick connection between the CGM/OVM and SUMMATM canisters.

6.D4 Connect the CGM/OVM to the c-flex.

6.D5 Open the sample line isolation valve, $\mathrm{V} 1^{\star}$.

6.D6 Purge the sample line using the CGM/OVM for the time specified in the field work package.

6.D7 Measure and record on the data sheet the ammonia concentration and the LFL reading and the time and date of these readings. 
6.D8 Close the isolation valve, $\mathrm{V} 1^{*}$.

6.D9 Disconnect the CGM/OVM from the.c-flex and connect the SUMMATM canister.

6.D10 Open isolation valve, $\mathrm{V} 1^{*}$.

6.D11 Collect the SUMMATM sample per field work package and record the data required on the data sheet (or data continuation sheet).

6.D12 Close isolation valve, $\mathrm{V} 1^{*}$.

6.D13 Disconnect the canister from the c-flex and then connect the second canister.

6.D14 Open isolation valve, $\mathrm{V} 1^{*}$.

6.D15 Collect the second SUMMA TM sample per the field work package and record the data required on the data sheet.

6.D16 Close isolation valve, $\mathrm{V}^{*}$.

6.D17 Disconnect the canister from the $\mathrm{c}-\mathrm{flex}$ and then connect the third canister.

6.D18 Open isolation valve, $V 1^{\star}$.

6.D19 Collect the third SUMMA ${ }^{\mathrm{TM}}$ sample per the field work package and record the data required on the data sheet.

6.D20 Close isolation valve, $\mathrm{V}^{*}$.

6.D21 Disconnect the canister from the c-flex.

6.D22 Label and control the three SUMMA ${ }^{\top M}$ canister samples per Appendix A.

6.D23 Configure the assigned sample point to the condition specified in the field work package. 


\section{References}

Huckaby, J. L., K.B. Olsen, D.S. Sklarew, J.C. Evans, and K.M. Remund, 1997, "Measurements of Waste Tank Passive Ventilation Rates Using Tracer Gases," PNNL-11683, Pacific Northwest National Laboratory, Richland, Washington.

Peurrung, L.M., L.A. Mahoney, C.W. Stewart, P.A. Gauglitz, L. R. Pederson, S. A. Bryan, C.L. Shepard, 1998, "Flammable Gas Issues in Double Contained Receiver Tanks," PNNL 11836 Revision 1, Pacific Northwest National Laboratory, Richland, Washington.

U.S. Department of Energy, Richland Operations Office (DOE-RL), 1996, "Hanford Analytical Services Quality Assurance Requirements Documents," DOE/RL-96-68, United States Department of Energy Richland Operations Office, Richland, Washington. 
HNF-2543, Rev. 2

Appendix $\mathrm{A}$

Sample Identification, Control, and Data Recording 


\section{A.1 Radiation Screening}

Characterization Project Operations shall maintain all vapor samples under chain-of-custody requirements while performing a radiological survey of certain items used during sampling. Surveys are conducted to assure compliance with Department of Transportation shipping regulations and offsite laboratory acceptance criteria. See the Radiation Survey Plan in the field work package for details.

\section{A.2 Sampling Operations}

The CPO shall provide unique sample label and identification numbers to the laboratories. Each sample identification number shall have the following format:

\section{VXXXX-YYY-LLLL}

where,

$V=$ indicates that sample is a vapor sample

$X X X X=$ unique number assigned to the sampling event by CPO

YYY $=3$ digit code found on the data sheet canister)

LLLL = laboratory assigned code (this number is on a tag attached to the SUMMA ${ }^{\mathrm{TM}}$

Once CPO has received the sample collection media (SUMMA ${ }^{\text {TM }}$ canister) it shall remain in the physical control of the custodian, locked in a secure area, or prepared for shipping with tamper evident tape under conditions specified on the chain-of-custody form.

Applicable operating procedures for the tank vapor space sampling activities are contained in the appropriated work package.

All sampling activities shall be documented in the field work package maintained by CPO and shall contain, but are not limited to:

- Identification of tank and sample point and photographs (as applicable) of the sample location in which sampling is conducted,

- If any anomalies are observed, corresponding sample identification numbers, flow rates, pressures, temperatures, and other operational parameters affecting the sample are to be recorded,

- Any conditions that the sampler may observe during the sampling event (i.e. odors, nearby machinery in operation) are to be recorded, and

- Names and titles of personnel involved in the field activity and their responsibilities.

A copy of the completed data sheet and completed chain-of-custody forms is to be transmitted to the Safety Issue Resolution Organization. 
HNF-2543, Rev. 2

\begin{tabular}{|c|c|c|c|c|c|}
\hline & T Bre & hing & ate [ & ihee & \\
\hline Tank Number: & & & & & \\
\hline & Sample & & Time & ure) & Onondet \\
\hline Data Deschiptout & No. & Dale & Start & Stop & \\
\hline Sample Set 1 & A01 & & & & \\
\hline & A02 & & & & \\
\hline & $\mathrm{A} 03$ & & & & \\
\hline LFL Reading: & & & & N/A & \\
\hline Ammonia Conc.: & & & & N/A & \\
\hline DRI Survey No.: & & & N/A & N/A & \\
\hline Tracer Gas Injection & N/A & & & & \\
\hline $\begin{array}{l}\text { Gas Cylinder } \\
\text { Temperature: }\end{array}$ & & & & N/A & \\
\hline Sample Set 2 & B01 & & & & \\
\hline & B02 & & & & \\
\hline & $\mathrm{BO3}$ & & & & \\
\hline $\begin{array}{l}\text { Tank Wasie } \\
\text { Temperature: }\end{array}$ & & & & N/A & \\
\hline Sample Set 3 & $\mathrm{C} 01$ & & & & \\
\hline & $\mathrm{C02}$ & & & & \\
\hline & $\mathrm{C} 03$ & & & & \\
\hline Ammonia Conc.: & & & & N/A & \\
\hline LFL Reading: & & & & N/A & \\
\hline DRI Survey No.: & & & N/A & N/A & \\
\hline
\end{tabular}


HNF-2543, Rev. 2

\begin{tabular}{|c|c|c|c|c|c|}
\hline \multicolumn{6}{|l|}{ DCRT Bre } \\
\hline \multirow{2}{*}{ Data Description } & \multirow{2}{*}{$\begin{array}{l}\text { Sample } \\
\text { No. }\end{array}$} & & \multicolumn{2}{|c|}{ Time (or Pressure) } & \multirow[b]{2}{*}{ Recorded By } \\
\hline & & Date & Start & Stop & \\
\hline \multirow{3}{*}{ Sample Set 4} & D01 & & & & \\
\hline & $\mathrm{D} 02$ & & & & \\
\hline & $\mathrm{D} 03$ & & & & \\
\hline \multicolumn{2}{|l|}{ LFL Reading: } & & & N/A & \\
\hline \multicolumn{2}{|l|}{ Ammonia Conc.: } & & & N/A & \\
\hline \multicolumn{2}{|l|}{ DRI Survey No.: } & & N/A & N/A & \\
\hline \multirow[t]{3}{*}{ Sample Set 5} & E01 & & & & \\
\hline & E02 & & & & \\
\hline & E03 & & & & \\
\hline \multicolumn{2}{|l|}{ LFL Reading: } & & & N/A & \\
\hline \multicolumn{2}{|l|}{ Ammonia Conc.: } & & & N/A & \\
\hline \multicolumn{2}{|l|}{ DRI Survey No.: } & & $\mathrm{N} / \mathrm{A}$ & N/A & \\
\hline \multirow[t]{3}{*}{ Sample Set 6} & F01 & & & & \\
\hline & F02 & & & & \\
\hline & $\mathrm{F} 03$ & & & & \\
\hline \multicolumn{2}{|l|}{ LFL Reading: } & & & N/A & \\
\hline \multicolumn{2}{|l|}{ Ammonia Conc.: } & & & N/A & \\
\hline \multicolumn{2}{|l|}{ DRI survey No.: } & & N/A & & \\
\hline
\end{tabular}




\section{DISTRIBUTION SHEET}

\begin{tabular}{|c|c|c|c|c|c|}
\hline \multirow{2}{*}{$\begin{array}{l}\text { To } \\
\text { Distribution }\end{array}$} & \multirow{2}{*}{\multicolumn{3}{|c|}{$\begin{array}{l}\text { From } \\
\text { Safety Issue Resolution, } \\
\text { Flammable Gas Project }\end{array}$}} & \multicolumn{2}{|l|}{ Page 1 of 1} \\
\hline & & & & \multicolumn{2}{|c|}{ Date July 31, 1998} \\
\hline \multirow{2}{*}{\multicolumn{4}{|c|}{$\begin{array}{l}\text { Project Title/Work Order } \\
\text { Test Plan for Headspace Gas Concentration Measurement and Headspace Ventilation Rate } \\
\text { Measurement for DCRTs } 241-\mathrm{A}-244,241-\mathrm{BX}-244,241-\mathrm{S}-244,241-\mathrm{TX}-244\end{array}$}} & \multicolumn{2}{|c|}{ EDT No. 613764} \\
\hline & & & & \multicolumn{2}{|c|}{ ECN No. 623527} \\
\hline Name & MSIN & $\begin{array}{l}\text { Text } \\
\text { With All } \\
\text { Attach. }\end{array}$ & Text Only & $\begin{array}{l}\text { Attach./ } \\
\text { Appendix } \\
\text { Only }\end{array}$ & $\begin{array}{c}\text { EDT/ECN } \\
\text { Only }\end{array}$ \\
\hline
\end{tabular}

Correspondence Control

A3-01

Lockheed Martin Hanford Corporation
W. B. Barton
R2-12
D. C. Board
S7-07
J. N. Doelor
T4-07
D. J. Green
S7-04
R. S. Nicholson
S5-05
J. S. Schofield
S7-12
G. A. Stanton
$57-21$
M. L. Sumsion
$57-03$
M. J. Sutey
D. D. Wanner
T4-08
S7-12

DE\&S Hanford, Inc.
R. E. Bauer
$57-73$
R. J. Cash
S7-73
J. M. Grigsby
S7-73
G. D. Johnson
S7-73
G. W. Ryan
R1-44

Pacific Northwes National Laboratory

J. L. Huckaby

K6-80

M. W. Goheen

P7-22 